\title{
Reuse of historic naval hospitals
}

\author{
C. M. Clark \\ Wessex Institute of Technology, UK
}

\begin{abstract}
In this paper we assess the futures of historic naval hospitals - once the sailors have left leave - as contributions to the achievement of the sustainable city.

Hospitals for nations' navy sailors were built in the eighteenth and nineteenth centuries in many countries, their impressive design reflecting pride in national fleets and in the sailors who manned them. Naval physicians and surgeons devised many innovative therapies and cures, contributing greatly to international medical knowledge. They also developed therapeutic architecture. Defence cuts and reductions in the defence estate have left several grand naval hospital complexes empty and looking for new uses. Whether they have viable futures depends on many factors: differing processes of state land disposal, civilian planners' actions, legislation to protect historic structures, location, financing for adaptive reuse, the state of local economies, and campaigning by national bodies and local communities to ensure that future uses accord with their distinguished pasts. This paper examines naval hospitals' history, design and the transition to the many and varied civilian uses achieved once redundant. It draws on examples from the United States and Europe. Naval hospitals' new roles as universities, training establishments and schools, museums, offices and workshops, residences and medical centres contribute to the achievement of the sustainable city, but the fate of some important examples remains uncertain.
\end{abstract}

Keywords: naval hospital, therapeutic architecture, sustainable reuse.

\section{Introduction}

"In all well regulated armies and navies, physicians and surgeons are appointed to take charge of those who are wounded; or who suffer by the insidious attack of disease." Edward Cutbush 1808 [1]. Sailors' life on board national fleets was brutal and dangerous, their diet monotonous, hygiene and sanitation minimal. They suffered war wounds, burns, splinter injuries, tropical fevers, mental 
illness, 'the bloody flux', the effects of malnutrition and venereal disease. 'The space allocation for the sick was limited in the extreme; isolation was impossible.' In the eighteenth century, the number of British sailors who died from disease or wounds far exceeded those killed by enemy action [2].

In the UK the history of naval medical treatment can be traced back to the establishment of the Chatham Chest in 1590, kept in Chatham Parish Church, to which each parish contributed a weekly sum for the maintenance of sailors born or resident within its boundary [3]. Medical artefacts - a pewter syringe and cupping bowl from a barber-surgeon's chest - survive from the wreck of the sixteenth century Henry VIII's flagship Mary Rose, raised from the seabed off Portsmouth England in 1982. Before naval hospitals were built ashore, sick sailors were housed aboard hospital ships and ashore in contracted premises, often inns or alehouses. Two hospital ships including the San Pedro el Mayor of 550 tons with 50 medical personnel on board accompanied the Spanish Armada in 1587 to 1588 . The British Royal Navy used the Goodwill for the same purpose in an expedition to the Barbary coast in 1620 . They continued to do so up to the Falklands war of 1982 [4].

In Britain a structured naval medical service has existed since 1512, if not earlier, owing its origins to the insights and engineering genius of Henry VIII [5]. Farsighted naval physicians such as William Clowes, George Watson, James Lind, Gilbert Blane, Thomas Trotter and many others sought to improve medical treatment and surgery - once the sailors had reached hospital after initial treatment on board during battle by barber-surgeons. Naval physicians and surgeons devised many innovative therapies and cures, contributing greatly to international medical knowledge; pioneers not only in surgery and medicine, but also in the development of therapeutic architecture. There is no space in this short paper to examine their considerable and ongoing innovations.

From the seventeenth century many countries built hospitals for their sailors, their impressive design reflecting pride in national fleets and in sailors' achievements in war or in keeping the peace. However, from the mid twentieth century defence cuts and reductions in the defence estate have left grand naval hospital complexes empty and looking for new uses, which some have achieved, making contributions to the sustainable city.

Using examples from the former British empire, South Africa and the United States, this paper examines naval hospitals' design as therapeutic architecture; the causes of their redundancy and the disposal process; their cultural significance and local communities' aspirations for them; the new uses achieved in these impressive complexes once the navy leaves and their contribution to the sustainable city.

\section{Naval hospitals' architectural importance: therapeutic architecture}

There are several accounts of the development in naval medicine and hospitals in Britain, France and the United States [6]. The classical style was considered the most appropriate for the new building type. In Britain, the Royal Naval Hospital 
at Greenwich on the River Thames is celebrated as "the most stately procession of buildings we possess" (Sir Charles Reilly). It was established in 1694 by Royal Charter for the relief and support of seamen and their dependents. It "was intended not for the eyes of the sick and wounded, but for those who survived the rigours of service life and needed a home in their old age' [2]. Nicholas Hawksmoor, Sir John Vanbrugh, John Webb and Thomas Ripley helped to complete Wren's grand design. By 1815 2,710 seamen lived there. The main hospital closed in 1869; in 1873 the Royal Naval College moved into it from Portsmouth.

Coad [2] says that at the beginning of the eighteenth century the methods of caring for sick and wounded seamen had hardly changed in two hundred years: they were boarded out in hired accommodation. During the Dutch Wars (16521674) the need for British naval hospitals became urgent. While the contract system was 'just about tolerable' at home, a combination of scurvy, tropical disease and fevers played havoc with the health of seamen overseas.

So the first purpose-built British naval hospitals were built in 1704 in Jamaica, in 1706 in Lisbon, and the first permanent building was erected in Minorca after its capture in 1708, predating those at home by thirty years. It was sited on the Isla del Ray midway between the harbour mouth and the town of Port Mahon from 1711-1712, isolated from the population and its wine shops and to deter potential deserters - a factor in later hospitals at Gibraltar and Haslar. A single-storey range 310 feet long it has wings at either end and a central chapel with domed bell tower, flanked by five vaulted wards linked by a colonnade. A second hospital for 1200 patients was added from 1772-4 in plain ashlar, punctuated by small windows and propped by massive buttresses. The wards were also linked by a colonnade opening out into a vestibule in front of the chapel, leading to a kitchen. The design and choice of materials were adapted to the climate: pale stone and small windows keeping the internal spaces cool. Unlike Haslar, no provision was made for communal eating. 'Devoid of all architectural embellishment, its plain ashlar walls punctuated by small windows and propped by massive buttresses, [it] can only be described as grim and forbidding' The hospital was subsequently used by the Spanish navy, but later became derelict [2].

The Naval Hospital in Gibraltar, probably to a design by Wibault [2], was a simple two-storey quadrangle, 350 feet long and 150 feet wide, with a central courtyard measuring 150 feet by 75 feet. Staff accommodation was provided in small three-storey corner towers, and ancillary facilities were behind the main east-west frontages. The hospital could accommodate $1000 \mathrm{men}$, twice the size of Minorca. In plan it was a mirror image of London hospitals, with long wards connected to one another via internal doors. One key innovation was the introduction of covered verandahs at ground level around the courtyard which protected patients from the heat and served as open-air corridors allowing wards to be isolated if the need arose. These corridors were a significant architectural advance. From 1741 to 1746 craftsmen from Portsmouth dockyard helped to complete it with bricks, timber and iron fittings from home. 
In South Africa the Dutch East India Company Governor Simon van der Stel established Simon's Town in 1743 as a strategic port. A company hospital with three front-facing gables was built on the mountainside above the Residency in 1764. The British established the South Atlantic station there in 1814, expanding it as a strategic a naval port of the British Empire. Old Hospital Terrace of 1814 was where Lord Lister's new antiseptic methods were used for the first time in South Africa. In the late 1890's the poet, author and playwright Edgar Wallace served here as a medical orderly [7].

From 1824 to 1863 , the British Government transformed Ireland Island Bermuda into a naval arsenal and fortress. A two-storey limestone hospital with a central dome designed by Vice-Admiral Sir Alexander Cochrane was built in 1814-8. Medical staff served heroically here during World War II [8].

Buchanan [3] sees similarities in the degree of humanitarianism and in the disposition of space between prisons and hospitals, both of which deprived people of their liberty. British naval hospitals served both purposes. Coad [2] makes the same point: 'Apart from the provision of medical care, there was little to choose between an early hospital of the Georgian navy and a prison'. British sailors spent many years at sea, many against their will. From 1664 to 1814, far from being volunteers, eligible men of seafaring habits between the ages of 18 and 45 were "pressganged" into the Royal Navy from maritime cities [9]. By contrast, "in the 17th century neither the Dutch nor the French had press gangs per se - the former relied on embargoes etc and the latter on a registration system.... the Spanish... also used compulsion in several (but not all) parts of their multiple kingdoms" [10]. Buchanan sees naval hospitals' high walls, sturdy massing and pared-down details as "expressive of a strict economy of means, but also of a strong sense of gravitas and authority. This visual authoritarian character was fundamental to the identity of a naval hospital, for whilst the prime intention was to provide efficient medical care, it was equally important to maintain discipline and prevent sailors from escaping. Isolated locations were chosen for the same reason.

In 1791 Jeremy Bentham published his Panopticon design for buildings based on the principle of the "all seeing eye" of the superintendent, adopted in John Conolly's The Construction and Government of Lunatic Asylums in 1847. Visual supervision - usually from a central point - was also the key to nineteenth British workhouses, the origins of many hospitals. The Admiralty were aware of the widespread developments in hospital design in London, Edinburgh and provincial cities. Naval hospitals sited near principal dockyards could provide an efficient and effective service so recovered sick and wounded sailors could be returned quickly to sea. The Sick and Hurt Board resolved to establish naval hospitals for the dockyards. In 1744, the Navy Board proposed to construct naval hospitals at Chatham, Portsmouth (Haslar) and Plymouth (Stonehouse). Chatham's hospital was not built until 1827-1828.

In June 1745, the Admiralty ordered a hospital to be built on an isolated peninsular in Portsmouth Harbour. Within high walls, Haslar hospital was constructed from 1746 to 1754 . It is amongst the most impressive of British naval buildings, designed by Theodore Jacobsen for 1500 patients based on the 
quadrangular principle first developed at Greenwich: double ranges of red brick embellished with Portland stone dressings, linked at their centres, separated by about 35 feet around a square courtyard; though the fourth side was never built. The architecture is domestic-institutional Georgian, with an affinity on a larger scale, with later storehouses in the dockyard [11]. Free circulation of air to prevent disease occupied the minds of leading scientists, naval doctors and inventors, but cross ventilation was not achieved here since no windows were provided on the ranges facing the light-wells. The chief disadvantage of the original design was that wards ran the full width, also having to serve as corridors, an inconvenient arrangement not in accordance with later medical practice. The Minorca hospital of 1711 where covered verandahs served as corridors was in advance in this respect. The largest brick building in Europe, reputedly Haslar was the largest hospital in the world [2].

Considered to be well ahead of its time, the design was successfully copied, in altered form, in hospitals at Plymouth and Chatham. By 1787 it had 84 general and surgical wards and consumptive and isolation wards, each with its own water closet: for flux, smallpox, consumptive, scorbutic and recovery wards, and wards for lunatics. A bathhouse was for newly admitted patients. In 1796 the open side of the quadrangle was closed by 12 foot iron railings to improve security. The first physician was Dr. James Lind, appointed in 1758. During his long term of office he did a great deal to raise medical standards in the navy and to ensure for Haslar's pre-eminence in naval medicine, which it retained for 250 years.

Haslar's contemporary, Stonehouse Hospital in Plymouth, was built from 1758 to 1762 . Medically an advance on the Haslar model, it was designed by Alexander Rovehead with help from William Robinson Clerk of Works to the Greenwich Hospital. Enlightenment clinical theory was committed to classifying disease, and Rovehead's plan embodied this objective: 'for the purpose of admitting freer circulation of air, and also of classing the several disorders, in such a manner, as may best prevent the spread of contagion'. Stonehouse was the first instance of eleven isolated three-storey pavilions with a linking colonnade. The blocks are in plain rubble stone with ashlar dressings. The central block, Trafalgar, originally housing the chapel, dispensary and dispenser's quarters has a cupola, a central Venetian window and an open arcade. The pavilions were five bays wide and three storeys high with two wards on each floor, divided by a spine wall containing two fireplaces to assist crossventilation. Widely regarded as the finest in Europe, far in advance of its time, it was not only a functional success, but an example of medicine and architectural design moving in tandem. The emphasis had shifted from the hospital as fortress to a place where ventilation and isolation were the key [3]. It clearly influenced the Military Hospital of 1797 on the other side of Stonehouse Creek.

Two prominent French scientists, Jacques-René Tenon, a surgeon, and Charles Augustine Coulomb visited it on July 11-14 1787 on a tour of the major hospitals of Europe with a view to reforms proposed by the Academie des Sciences in Paris. They declared that Stonehouse was 'this beautiful hospital, the most perfect that I know for its intended purpose'. The Stonehouse plan was 
modified in Tenon's Memoires sur les Hopitaux de Paris in 1788. Tenon and Bernard Poyet produced a pavilion plan for a new Hôtel-Dieu, and other versions of this model followed including J Lecointe's model military hospital of 1793, which shows a division into four parallel pavilions for the sick the wounded, the convalescent and administrative services, with bellows-type ventilators inserted at the end of the wards.

In 1722 the world's first School of Naval Medicine was established at Rochefort. In 1788 it was transferred to the new Naval Hospital there, built between 1783 and ' 88 outside the city walls by Pierre Toufaire. The School's library and its anatomical, surgical and natural history collections have made it a rare European example of a "cabinet of curiosities" preserved in its original setting, a town founded by Colbert on the orders of Louis XIV solely to service the dockyard. The buildings' dimensions, the large windows, and the pavilions which allowed the isolation of patients with contagious diseases made it a model of hospital planning. Naval schools of medicine were established at Toulon in 1725 and Brest in 1731 [6 Dean]. For the sailors of the Ottoman Empire the Naval Hospital: Melz Sokagi, distinguished by its central tower, was built in 1785 at Kasimpaşa, on the northern shore of the Golden Horn in Istanbul. It is still used by the Turkish navy.

In 1802 the hospital at Port Mahon was sixty years old, too far from fleets based at Grand Harbour at Malta. The Admiralty decided to convert the Villa Bighi in Malta, a neo-classical palace of 1675 into a naval hospital. In 1832 it was extended with light and airy wards. The main floor of administrative offices, officers' quarters and chapel is set on a massive rusticated and vaulted basement of storerooms, kitchens and dispensary visible across the Grand Harbour, giving it a monumental appearance [12].

In 1798 the United States Congress passed a Bill for the Relief of Sick and Disabled Seamen which established the Marine Hospital Service, the forerunner of the US Public Health Service. The fund to care for Navy personnel and the Merchant Marine was financed by deductions of twenty cents a month for every seaman arriving from a foreign port into any US port. It also authorised the President to use these funds "to cause buildings, when necessary, to be erected as hospitals for the accommodation of sick and disabled seamen." Edward Cutbush is credited with the establishment of the first US naval hospital between 1804 and 1806 at Syracuse, where the Mediterranean squadron was fighting the Barbary States (Brings [12] p.267). He inspected the hospitals of England, France and Germany, and published practical advice on hospital sites and buildings, stressing the importance of quarantine, cleanliness of patients and disinfection of clothing and bedclothes (Cutbush [1] 1808). A military hospital could serve as a teaching institute - following the example of Europeans. In 1811 the Navy Hospital Act established a board of Commissioners to administer the hospital fund and to "procure a suitable place or places proper sites for navy hospitals...." [13]. Engineer Latrobe and William C Barton published plans for marine hospitals in 1817 and 1814 drawing on naval hospital designs in Britain and France, but it was not until 1830 that the first permanent US naval hospital began to receive patients at Norfolk Virginia. 
By 1832 permanent hospitals were built at Charlestown Massachusetts, Brooklyn New York and Pensacola Florida. In Chelsea Massachusetts the hospital was designed by Alexander Parris (1780-1852), the prominent American architect-engineer of the Quincey Market in Boston and the Virginia Executive Mansion. John Haviland designed the Norfolk Virginia Hospital in granite and freestone, three storeys with a basement in a hollow square. Its entrance façade is embellished with a bold Doric portico. Particular attention was paid to ventilation, warming, superintendence and classification of the different wards. The Philadelphia Asylum was finished in 1833: "the large marble edifice was bustling with activity as it served as a home for the disabled, a general hospital and a school for midshipmen and the US Naval Academy had its origin there. Construction of the Naval Hospital in Washington DC began in 1864 during the Civil War, completed in 1866. Until 1911 it was the Hospital Corps Training School, where sailors learned nursing, hygiene and anatomy. From 1922 until 1963 it was a home for veterans pressing pension claims.

By 1838 Brooklyn Navy Yard's Greek Revival Naval Hospital in New York designed by Martin E Thompson was constructed from Sing Sing marble to the east of the yard in Wallabout Bay with a recessed colonnaded central portico. It was extended in 1840 to complete Thompson's u-shaped design. A pest house was converted into a laboratory for production of medicines, the fore-runner of the Navy's Medical Supply Depot which supplied more than half the medicines used by the Union troops in the Civil War [14]. Edward R. Squibb persuaded Congress to allocate for the Naval hospital Laboratory in 1857, starting his pharmaceuticals company in Brooklyn shortly afterwards. In 1845 Robert Mills, architect of the Smithsonian Institute and the Washington Monument designed the airy US Marine Hospital in Key West Florida for naval and civilian sailors.

One of the most imposing naval and military hospitals in the United States is the Army and Navy General Hospital at Hot Springs, Garland County Arkansas. Designed in the 1930s in Spanish Revival style with subtle Art Deco influences for both services, it specialised in the treatment of poliomyelitis and arthritis using the natural hot springs below. It also served as a training school for servicemen and servicewomen [15].

Despite national resistance to spending money on permanent naval hospitals, it is clear that US naval hospitals' construction was a matter of national pride.

"Every improvement in our materials, whether timber, cordage, or cannon - in our yards, docks or harbors - in our hospitals or asylums - will add strength to this moral force, and better prepare us for any future conflict in which the violence or injustice of other nations may involve us" Levi Woodbury Report of the Secretary of the Navy to President Jackson in 1833.

\section{Causes of redundancy and state land disposal processes}

From the mid to late twentieth century geo-political change combined with cuts in defence expenditure resulted in closure of many naval and military sites, including hospitals. Military property disposals continue to be a huge factor in many countries. US Websites list naval hospitals disposed of in successive 
rounds of defence cuts [16]. As my earlier paper indicated [17], since the early 1990 s, three waves of US military-base closings have resulted in the sale and conversion of more than a hundred thousand acres of federal land (and thousands of buildings) to private redevelopment. In 2008 the federal government pledged to purge military bases of 50 million unused square feet in the next five years. Disposal of defence land in Europe too, has rapidly gathered pace: the Bonn International Centre for Conversion estimate that up to 4,733 hectares - more than 8,000 sites - may have been transferred in the period from 1990 to 2000 . The effect on local economies of super-power withdrawal - in Asia as well as in Europe - has been considerable.

Naval hospitals are included in these closures. Brooklyn Naval Hospital was closed in 1948, its staff, patients and the bulk of its equipment transferred to the 1500-bed Naval Hospital in St. Alban's, Queens New York. Brooklyn Yard closed in 1966 and was sold to New York City two years later. In 2001 the City of New York purchased the site of the hospital from the Federal Government, which also transferred control of the site of the Washington Naval Hospital to the District of Columbia in 1972. The building housed social service organizations and headquarters for establishment of the Martin Luther King, Jr. national holiday. But it was not properly maintained; by 1998 it was vacant; the carriage house rented as offices for addiction treatment and counselling. In 1970 in the second rundown of British services in Malta, Bighi Hospital closed; Naval Medical Services were transferred to the Military Hospital at Mtarfa.

Different processes for disposal of state owned property - which range from free transfer to the homeless and other social entities controlled by locals in the Base Reuse process (the United States), to sale within three years to the highest bidder (the UK and Germany) inevitably result in widely varying outcomes, which may or may not contribute to the sustainable city. High sales prices lead to high financial return: leisure shopping or luxury housing, which may not match local needs and aspirations. The search for new uses once naval hospitals are no longer used by sailors, doctors and nurses is sometimes controversial. When the British Minister of Defence put the Royal Naval Hospital in Greenwich up for sale to the highest bidder in the 1990s there was a national outcry. Accusations of 'Selling the family silver' prompted withdrawal of this proposal. Instead, a foundation created to manage the site invited two universities to fill it. In contrast, the US Base Reuse process offers the homeless either defence buildings free of charge, or the fiscal benefit from disposal onto the commercial market - as in the case of a naval hospital in Missouri.

\section{Cultural status and local communities' responses}

The importance of naval hospitals as symbols of national pride is reflected in their designation by governments or by local authorities as protected monuments. Greenwich Royal Hospital is the centrepiece of a World Heritage site. In Simonstown South Africa the older dockyard buildings including the hospital have been declared National Monuments. The main Brooklyn hospital building and Surgeon's House of 1863 are both New York City Landmarks. The US 
Marine Hospital at Key West is on the National Register of Historic Places. Haslar Hospital is listed Grade II*, and the 31 buildings in 10 acres around the Army and Navy General Hospital in Hot Springs, Garland County Arkansas are designated a state-wide Historic District for its architecture and design in treatment of poliomyelitis and arthritis and as representative of 1930 military hospitals. The naval hospital at Rochefort is included on the Supplementary List of Historical Monuments.

Not all naval and military hospitals are legally protected. The buildings of the Port Royal base in Jamaica including the hospital, closed in 1904, have long since disappeared. The Royal Victoria Military Hospital (1856-63) on Southampton Water in Hampshire England, at 1,424 feet long, was deemed too large to reuse and demolished except for the central chapel. In Malta Bighi Hospital was used as a barracks; a Boy's Technical School occupied the central and east blocks. In 1984 the central block was abandoned because of lack of maintenance to dangerous ceilings.

Heritage status is sometimes seen either as an impediment or extra cost loaded onto the complex task of reuse or a useful barrier to unacceptable change. Countries differ in the degree to which physical change is permitted, while in some, such as Norway and the UK until 2006, the state was exempt from such civilian controls. As a consequence, despite its listed status, radical modernisation of Haslar Hospital in the 1960s and repair of WWII bomb damage totally remodelled the interior. A new Brutalist operation suite was inserted into the central courtyard; only a staircase in the south wing remains from the original interior. Leaving historic buildings empty for long periods especially if they are not wind and weather tight obviously results in serious deterioration of the fabric, damaging their value and exponentially increasing repair and adaptation costs. But Ministries of Defence - or their successor owners - may not be specifically funded to keep the naval and military heritage in good repair. Their overriding priority is to defend the country, which may lead to long term neglect of buildings they have no use for. Some of the naval buildings in Brooklyn Navy Yard including the Naval Surgeon's House have almost disappeared into a thickly growing jungle. Their past associations and layouts - isolation and high walls to contained pressganged navies such as the British - may paradoxically help with their reuse as self-contained entities: readymade gated communities. In Britain there are several examples of mental hospitals including naval ones being converted into residential complexes, their associations with emotional anguish forgotten, but their imposing architecture revalued.

Impressively, local communities sometimes initiate new lives for closed naval hospitals. In 2002, a diverse coalition of Capitol Hill residents in Washington DC organized the Old Naval Hospital Foundation to develop a comprehensive plan for an educational centre for children and adults and a community gathering place. In 2009 the DC Historic Preservation Review board unanimously approved the foundation's plans. Sunday volunteers, half Minorcan and half British residents of Minorca rescued the hospital in Port Mahon, led by the former chief of staff of the Spanish Army, General Luis Alexandre. He obtained a $30 \mathrm{ft}$ rigid-inflatable boat confiscated from drug smugglers to ferry visitors, 
volunteer workers and building materials, while military helicopters fly in heavier items. Collapsed roofs were recovered in traditional tiles, invasive scrub removed and a herb garden planted. The Roman Catholic chapel added after the British left was rededicated. The island's chemists and doctors have donated materials and equipment and the officers' quarters and commandant's house were fitted out with 19th-century furniture [18]. Determined and resourceful local authorities and local people constitute an effective combination to achieve sustainable uses for naval hospitals. Faced with a campaign by Gosport Borough Council and local residents who wanted to see Haslar Hospital continue in medical use, the British Ministry of Defence took the unprecedented step of employing the Prince's Foundation to organise an Enquiry by Design. Key stakeholders negotiated over three days to produce a master plan, building on the excellent conservation plan already prepared by the Borough's conservation officer and Defence Estates, the Ministry of Defence's property agency. The council adhered to its Local Plan, refusing residential conversion, which would have put up the site's value exponentially. What is needed is more jobs to replace those lost by the hospital's closure. But locals' dream of a dedicated centre for treatment of injured military and naval veterans may not be realised unless the purchaser of the site honours promises to set up a veterans' village and other medical and social uses to occupy it [22].

\section{Contributions to the sustainable city}

Bagaeen [19] proposed that the sustainable city is one that makes use of new forms of citizen participation, implements sustainable transport and mobility, promotes sound and healthy buildings, has an ecologically sound energy supply and minimises energy consumption, designs socially oriented living spheres with a mix of high density living and working space on brownfields while providing accessibility for different social groups.

Naval and military hospital buildings - or their sites - have the potential to contribute to development of the sustainable city in many different ways. As cleared sites they offer the opportunity to be built on again - or to provide new public parks. Rarely do these hospitals continue in medical use. Because of their size, naval hospitals lend themselves to continued institutional use, particularly education and training. The most prominent English example is the two universities: Greenwich and Trinity College of Music now installed in the Royal Naval Hospital at Greenwich. The public can access the whole World Heritage site, including the magnificent buildings, which often feature as historic film locations. Public access is important to community engagement in the future of these places. Isolated behind high walls they may be unknown to their host communities unless people worked there or were patients. Closed to the public for 208 years, Brooklyn Navy Yard is such a prominent part of the waterfront that the tours conducted by the Brooklyn Historical Society since 2008 have proved very popular. They attract former personnel, local people and foreign visitors [20]. The exterior of the Marine Hospital at Key West, converted into a condominium, is visible from the street in the Truman Annex. The University of 
La Coruna in Spain occupies several naval buildings. Mixed use, often achieved over a long period, is perhaps most useful to maintaining a site's sustainability. Stonehouse Hospital in Plymouth in southwest England illustrates that a longterm phased approach often yields the most sustainable reuse. The chapel and northern buildings have been taken over by a private school, and the rest of the campus is in mixed use: offices, some residential including newbuild, and service companies. A boys' comprehensive school occupies the buildings of the adjacent military hospital of 1797 across the filled-in Stonehouse Creek [21].

Residential use, particularly high-end housing is often the result of disposal systems which require sale to the highest bidder. Gibraltar's hospital was already converted to married quarters before it became available for civilian residential use. Rochefort's magnificent naval hospital may become residential, although it has stood empty for some years without any work beginning.

Heritage tourism and museums are often considered appropriate to these sites' contribution to national histories. This may be the ultimate destination for Port Mahon hospital. Rochefort's impressive medical library is open to the public, although the rest of the site is not. British naval medical records and artefacts from Stonehouse and Haslar hospitals have been moved to the library at the Royal Naval School of Medicine in Alverstoke Gosport, near Haslar Hospital.

Several naval hospital sites contribute directly to sustainable development, offering model exemplars closest to Bagaeen's definition. Brooklyn Navy Yard in New York has remained, thanks to its owner, the City of New York and its occupier, the Brooklyn Navy Yard Development Corporation, determinedly industrial, with special emphasis on sustainable research and development though its hospital site is not yet reused. The Corporation plans to redevelop the hospital as an entertainment and media campus in association with the large new Steiner Studios already in the yard. Innovative products developed in the yard include a prototype wind- and solar-powered street lamp; if successful in trials these will be rolled out all over New York. The new Perry Building was built to the highest energy standards with the first building-mounted wind turbines.

A much smaller example is the Sustainability Centre on the South Downs at East Meon in Hampshire England, which has been developed on the site of a naval signal station, HMS Mercury. The administrative block for the Sustainability Centre once housed a Naval Medical Unit. The centre's boiler using wood grown on site is creating sustainable energy for the whole site, now self sufficient domestic heating and hot water, and soon to generate $30 \%$ of their electricity. The youth hostel is rentable and restored to a high thermal standard. Income comes from the eco-publishing firm and another that does eco-audits housed in the building; woodland burials support educational activity.

\section{Conclusion}

Appropriate longterm new uses for these special places, so bound up with national pride, require several key factors. The most important is vision - by an individual, local government, successor owner or local community. Naval hospitals' intangible value, bound up with memory and association with 
suffering, therapy and care, needs to be respected in their subsequent existence. Disposal systems for state land most likely to achieve sustainability need to have longterm urban or rural regeneration built into their processes - as in the United States and Sweden, but not in the UK. Lastly, allowing time for these precious sites to develop and evolve, rather than forcing a quick fix upon them, makes their new lives as new quarters of the sustainable city most likely to be achieved.

\section{References}

[1] Cutbush Edward Observations on Preserving the Health of Soldiers and Sailors; and on the Duties of the Medical Department of the Army and the Navy; zwith Remarks on Hospitals and their Internal Arrangements Philadelphia Thomas Dobson 1808

[2] Coad JG 1989 The Royal Dockyards 1690-1850 Architecture and Engineering Works of the Sailing Navy p.293 Royal Commission of the Historical Monuments of England Scholar Press Aldershot

[3] Buchanan 2005 'An enlightened age: Building the naval hospitals' International Journal of Surgery Volume 3, Issue 3, 2005, Pages 221-228 Elsevier Ltd.

[4] Email from John Hailey to Celia Clark 9 December 2009; John J Keevil, Christopher Lloyd and Jack LS Coulter 1963 Medicine and the Navy: 1200 - 19604 vols. E S Livingstone Ltd. Edinburgh and London vol 1 page 73); Richard C Dean Naval Medical Schools of France and England Washington Government Printing Office 1876; Plumridge John 1975 Hospital Ships and Ambulance Trains. Seeley; Barton William P C 1814 A Treatise Containing a Plan for the Internal Organization and Government of Marine Hospitals, in the United States: Together with Observations on military and Flying Hospitals, and a Scheme for Amending and Systematizing the Medical Department of the Navy Philadelphia

[5] Watt James 1985 'Some forgotten contributions of naval surgeons' Journal of the Royal Society of Medicine Volume 38 September 1985 pp. 753-762

[6] www.facebook.com/note.php?note_id=47511470750

[7] www.bermuda-online.org/rnd

[8] Wikipedia www.en.wikipedia.org/wiki/Impressment accessed 6 October 2009

[9] Davies David 2009 Email to Celia Clark 6 October

[10] Lloyd David 1974 Buildings of Portsmouth and Its Environs City of Portsmouth

[11] Savona-Ventura C Naval Hospitals in Malta

[12] Brings Hans A 1986 'Naval Medicine Comes Ashore: Establishing the First Permanent US Naval Hospitals' Journal of the History of Medicine and Allied Sciences 41 pp.257-292 Oxford University Press http://jhmas.oxfordjournals.org/cgi/pdf_extract/41/3/257

[13] Delavan Bloodgood 'Naval Hospital, Brooklyn' A Naval Encyclopaedia Comprising a Dictionary of Nautical Words and Phrases; Biographical 
Notices, and Records of Naval Officers...Philadelphia LR Hanmersly 1881; Da Rosa

[14] www.geocities.com/HotSprings/2615/medhist/hospital5.htm accessed 6 October 2009

[15] www.fas.org/man/gao/ns96149.htm accessed 9 November 2009

[16] Clark Celia 2009 'Drosscapes or Brownfields? Differing processes to bring redundant industrial land, including military sites, back into productive use' Sustainable Development and Planning !V Vol.1 pp.175-186 ISBN 978-164564-424-6 Wessex Institute of Technology

[17] Binney Marcus 2009 The Times March 3 'Volunteers rescue British Naval hospital'

[18] Bagaeen, Samer Ghaleb 2006 'Redeveloping former military sites: Competiveness, urban sustainability and public participation' Cities Vol.23 No.5 pp.339-352 Elsevier Ltd.

[19] http://citynoise.org/article/8835 accessed 3 October 2009-12-18

[20] Cherry Bridget \& Pevsner Nikolaus 1991 Devon The Buildings of England Penguin Books London

[21] Dr. Roger Saunders University of Brighton Email to Celia Clark 1 February 2010 